\title{
A Hypothesis for Mechanisms of Weakness Distribution in Muscular Dystrophies
}

Israel Steiner*, Alexander Khlebtovsky and Felix Benninger

Department of Neurology, Rabin Medical Center, Campus Beilinson, Petach Tikva, Sackler Faculty of Medicine, Tel Aviv University, Tel Aviv, Israel

\begin{abstract}
Objective: The distribution of muscle weakness in muscular dystrophies varies, involving proximal muscles, distal muscles, or both. The mechanism underlying the differences in distribution is unknown.

Method: We compare and analyze the location and function of the culprit proteins responsible for muscle diseases and show that muscle weakness often follows a common pattern.

Results: Muscular dystrophies causing proximal weakness are due to mutations in genes coding for membranebound proteins, while conditions causing a predominantly distal muscle weakness are due to abnormal intracellular
\end{abstract} functional proteins of the sarcomere, the Z-disk or the cell metabolism.

Conclusion: This classification could enable predicting the function of newly identified myopathy-related genes according to their clinical presentation.

Keywords: Muscle; Muscle dystrophy; Muscle weakness

\section{Introduction}

Weakness distribution is a key element in muscle diseases. It may involve proximal or distal muscles, and this division is sometimes characteristic of the disorder. However, the reason for the dichotomic distribution remains a challenging and enigmatic feature of primary muscle syndromes.

Recent years have shown an impressive increase in knowledge regarding the genetic, metabolic, physiologic and structural basis of muscles in health and disease. This includes understanding the inner structure and location of muscle proteins, their function, and their genetic predisposition to mutations [1]. Based on these new discoveries, we propose that the intracellular location and the function of proteins involved in the pathogenesis of muscular dystrophies (MD) determines the anatomic distribution of weakness - proximal, distal, or both (Figure 1).

\section{Literature Review}

\section{The hypothesis}

We hypothesize that the intracellular location and function of proteins involved in the pathogenesis of MD determine the distribution of weakness. Those causing proximal weakness are due to abnormal proteins located on the muscle membranes, including outer (sarcolemma) and inner (sarcopalsmatic reticulum, the nuclear membrane) membranes. Those causing a predominantly distal muscle weakness connect to functional intracellular proteins of the sarcomere or the Z-disk. Thus, dysfunction in proteins associated with the protection of membranes, and those involved in the regeneration and repair after membrane injury, lead to proximal muscle weakness. On the other hand, proteins implicated in distal muscle weakness are involved in inner sarcomere mechanics and stability of the Z-disk.

\section{Testing the hypothesis}

Our premise, illustrated below, focuses on the location and function of the culprit gene products in the various muscle abnormalities.

\section{Proteins of the proximal MD}

Dystrophin is a membrane protein linking actin filaments to the sarcolemma that is thought to contribute to protecting muscle fibers from micro-tears during contraction [2]. Mutations in the dystrophin gene cause Duchene Muscular Dystrophy and Becker muscular dystrophy. The clinical phenotype is that of progressive proximal myopathy [3]. Sarcoglycans are proteins connected to dystrophin and the muscle cell membrane. In conjunction with dystrophin they build a dystrophin-glycoprotein complex that participates in muscle membrane stabilization during contraction, and its dysfunction leads to proximal weakness (Figure $2 \mathrm{~A}$ ). The caveolins are proteins involved in building invaginations observed in muscle membrane that are responsible for molecular signaling and lipid regulation [4]. Disease mechanisms include a reduced half-life of caveolin and the aggregation of mutated caveolin-3 in the Golgi apparatus. Mutations in caveolin-3 cause a proximal myopathy (Table 1).

Mutations in the gene for collagen VI underlie Bethlem myopathy, which causes proximal weakness. Collagen VI is located on the outer surface of muscle membrane, as part of the extracellular matrix, and probably functions as an anchoring protein between muscle basement membrane and the surrounding tissue [5]. Lamin A/C, located in the near nuclear membrane, is involved in membrane integrity and signaling. Lamin A/C dysfunction increases the vulnerability of the nuclear membrane to mechanical strain and induces changes in nuclear

*Corresponding author: Israel Steiner, Department of Neurology, Rabin Medical Center, Campus Beilinson, Sackler Faculty of Medicine, Tel Aviv University, Tel Aviv Campus 49100, Petach Tikva, Israel, Tel: 97239376351; E-mail: isteiner@cc.huji.ac.il

Received August 16, 2018; Accepted September 26, 2018; Published September 29, 2018

Citation: Steiner I, Khlebtovsky A, Benninger F (2018) A Hypothesis for Mechanisms of Weakness Distribution in Muscular Dystrophies. J Neurol Disord 6: 389. doi:10.4172/2329-6895.1000389

Copyright: (C) 2018 Steiner I, et al. This is an open-access article distributed under the terms of the Creative Commons Attribution License, which permits unrestricted use, distribution, and reproduction in any medium, provided the original author and source are credited. 
Citation: Steiner I, Khlebtovsky A, Benninger F (2018) A Hypothesis for Mechanisms of Weakness Distribution in Muscular Dystrophies. J Neurol Disord 6: 389. doi:10.4172/2329-6895.1000389

mechano-transduction. It underlies the proximal pattern of limb girdle muscular dystrophy type 1B (LGMD1B) [6]. Emerin is a nuclear membrane protein attaching lamin $\mathrm{A} / \mathrm{C}$ filaments to the nuclear membrane. Mutations in the emerin gene cause proximal EmeryDreifuss muscle dystrophy [7].

\section{Proteins of the distal MD}

The ZASP protein, located at the Z-disk, is thought to play a role in connecting titin fibers to the $\mathrm{Z}$-disk via $\alpha$-actinin. ZASP gene mutations cause a slow progressive weakness of soleus and gastrocnemius muscles, with a later progression to the distal muscles of the upper extremities known as Markesbery-Griggs MD [8]. Myosin-7 is part of the heavy chain of slow muscle type (Type I) and is a constituent of the sarcomere. Mutations in the myosin 7 gene are responsible for Gower-Laing muscular dystrophy that consists of distal weakness of dorsiflexion beginning in childhood with slow progression [9]. aB-crystallin (CRYAB), located near the Z-disk, has high affinity to desmin and titin, and protects myosin from premature destruction. Several mutations in CRYAB were shown to cause distal MD (Figure 2B). Glucosamine(UDP-N-acetyl)-2-epimerase/N-acetylmannosamine kinase (GNE) is an enzyme located in the cytoplasm, Golgi apparatus, and nucleus (Table 2). It is responsible for the synthesis of sialic acid and is involved in cellular signaling [10]. Mutations in the GNE gene are responsible for distal myopathy with rimmed vacuoles (Nonaka distal MD) [8].

VCP is involved in a number of essential cellular processes such as apoptosis, cell cycle control, membrane fusion, transcription activation and ubiquitin-mediated protein degradation. It causes structural changes in target proteins using mechanical force. Mutated VCP was shown to cause distal MD [11]. Kelch-like $(K L H L)$ gene family is a group of proteins that are involved in antioxidant responses, organization of actin cytoskeleton and protein ubiquitination [12]. Abnormality in KLHL-9 causes distal MD. Matrin-3 is a protein located in the nucleus that is thought to stabilize mRNA transcripts and DNA repair. Mutations in the nuclear matrix protein matrin-3 cause vocal cord paralysis with pharyngeal weakness and distal myopathy (VCPDM) [13].

\section{Defective proteins that involve both proximal and/or distal muscles}

Mutations in several key proteins cause both proximal and/or distal muscle weakness. These combined muscle diseases can be divided into two types: i) Mutations presenting with either proximal or distal weakness. ii) Mutations causing both proximal and distal weakness. Titin is a giant protein responsible for muscle elasticity and sarcomere organization that protrudes between two adjacent sarcomeres. It is responsible for sarcomere support and signaling. Mutations in the titin gene can cause either distal tibial myopathy (TMD), or a proximal myopathy of limb girdle type (LGMD2J) [14]. During eccentric contraction, titin increases its stiffness and as a result there is an increase in muscle force upon stretch [15]. When this function is lost, there is extensive proximal muscle damage (Tables 3 and 4). The two phenotypes (distal and proximal weakness) can be explained by the different isoform expressions of titin, as distal muscle have longer titin isoforms with a trend to associate with faster muscles and higher passive tension compared to proximal muscles (Figure 2C).

Nebulin, like titin, is a giant sarcomere protein regulating the length of thin filaments. Mutations in the nebulin gene either lead to a distal $\mathrm{MD}$ or, as nemaline rod myopathy (NEM2), a primarily proximal weakness later progressing to distal involvement. Dysferlin is located at the sarcolemma and thought to be involved in muscle membrane repair, possibly by regulating $\mathrm{Ca}^{2+}$ induced membrane fusion. Mutations in the large dysferlin gene lead to either a distal MD, the Miyoshi Myopathy, or to a proximal MD, limb girdle muscular dystrophy type 2B (LGMD2B) [16]. The wide spectrum of mitochondrial abnormalities in patients and impaired vesicle migration in dysferlin null muscle fibers in vivo might explain the wide range of phenotypes in dysferlinopathies. Desmin is an intermediate filament that is bound to the Z-disk, to the muscle

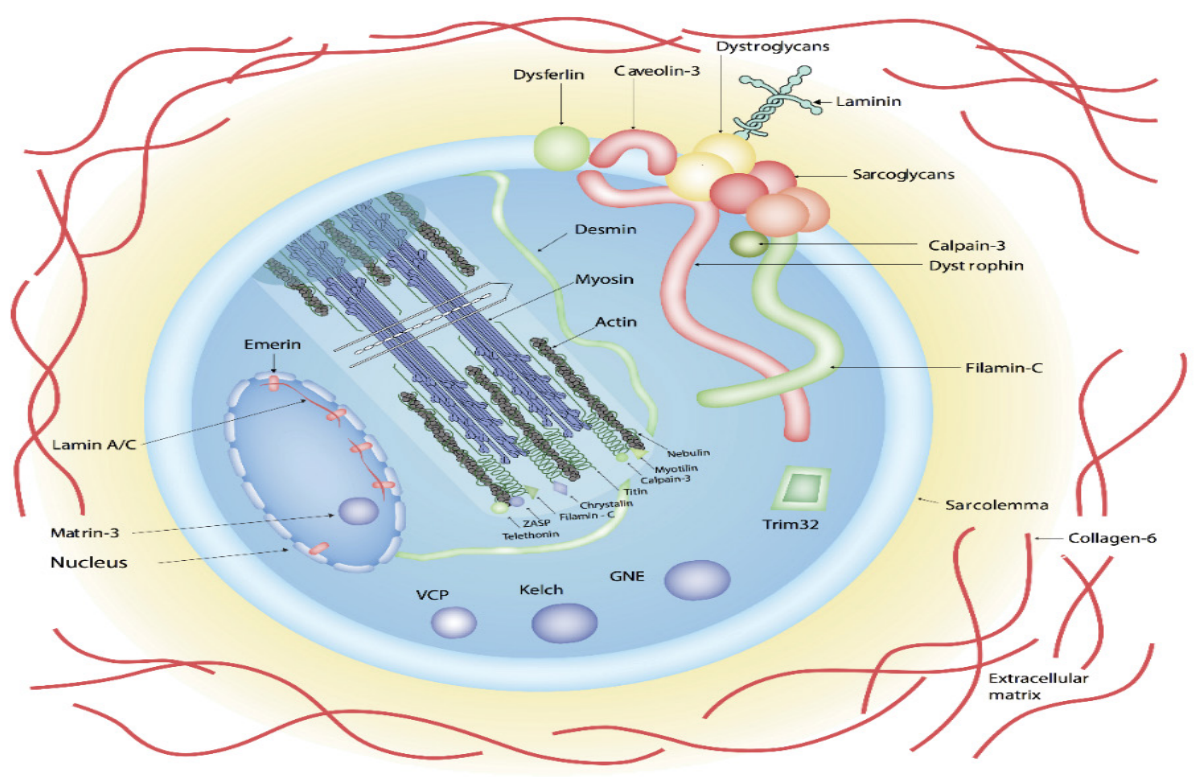

Figure 1: A schematic cross section of a muscle fiber depicting the probable location of proteins causing different types of muscle dystrophies.

Note: Proteins causing proximal MD are highlighted in red: caveolin and sarcoglycan complex proteins, outer muscle membrane collagen $\mathrm{VI}$, muscle membrane protein dystrophin, and nuclear membrane proteins emerin and Lamin A/C. In blue, proteins causing a distal MD: Myosin, Z-disk protein crystallin, cellular proteins VCP, KLHL9, GNE-epimerase and iternuclear protein Matrin-3. In green, proteins causing a proximal and distal myopathy: titin, calpain-3, filamin-C, telethonin, dysferlin, desmin and TRIM-32. 

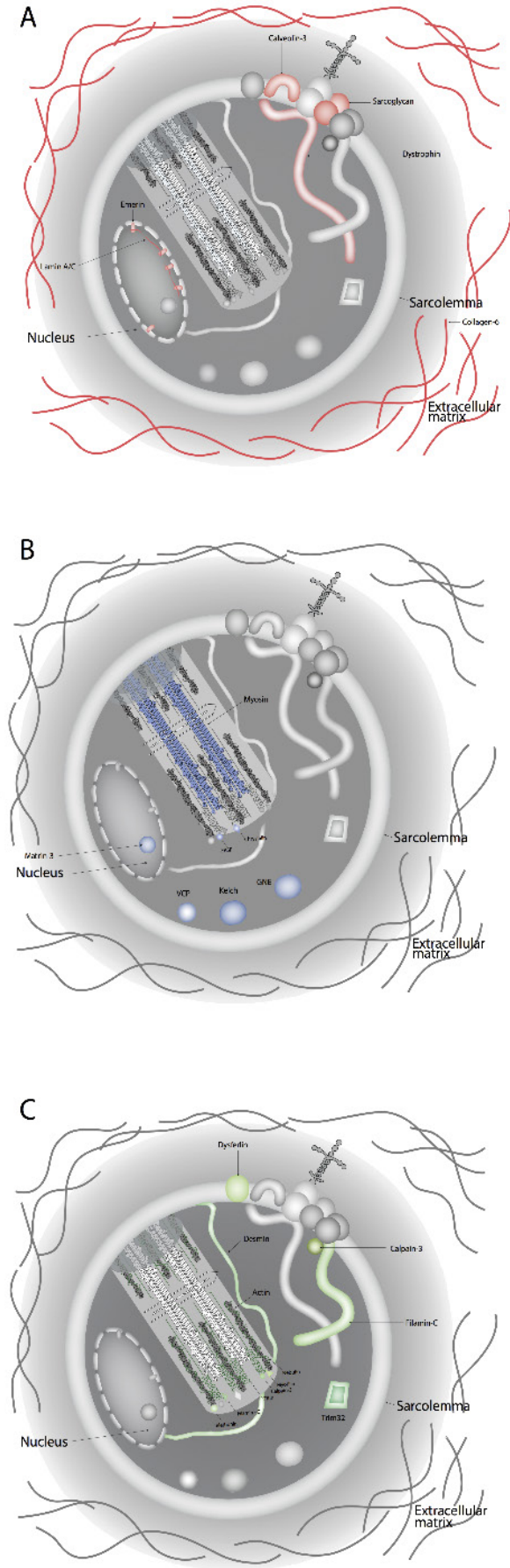

Figure 2: A schematic cross section of a muscle fiber. Proteins causing proximal, distal, or proximal and distal weakness are presented. (A) Probable location of proteins causing proximal MD. (B) Probable location of proteins causing distal MD. (C) Probable location of proteins causing distal and proximal MD).

nuclear membrane, and to extracellular matrix. Normal eccentric muscle contractions cause extensive damage to desmin fibers. Thus, desminopathies have a wide range of phenotypes: proximal weakness with mitochondrial dysfunction of fast muscles; Emery-Dreifuss like syndrome; and even a myasthenic syndrome. Most common, however, is a progressive myopathy involving distal muscles. However, cases were also reported of severe diffuse weakness, myopathy with cardiomyopathy [17], isolated cardiomyopathy, and limb girdle pattern of weakness (LGMD1E) [18].

Myotilin is a Z-disk protein involved in sarcomere stabilization. Mutations in myotilin cause proximal myopathy similar to that of LGMD1A. A far more common phenotype of myotilin gene mutation is a late onset distal MD, probably attributed to the involvement of myotilin in myofibrillar remodeling after eccentric muscle contractions $[19,20]$. Filamins are proteins responsible for actin crosslinking in the cytoskeleton. Filamins also interact with $\gamma$ - and $\delta$-sarcoglycans at the sarcomere membrane [21]. Mutations at the $\mathrm{N}$-terminus of filamin-C cause distal MD, but in four German families the presentation was mainly of proximal limb girdle manner.

Calpains are a group of proteases involved in protein ubiquitination. Mutations in the calpain-3 gene cause LGMD2A present as weakness of the glutei and hip adductors, together with involvement of soleus muscle and winging of the scapula [22].

Telethonin is one of the $\mathrm{Z}$-line proteins. Its $\mathrm{N}$-terminal is connected to titin and ot stabilizes the interaction between titin and the Z-disk. Telethonin has a role in muscle maturation by regulating the stiffness of slow twitching muscles and is involved in myostatin regulation pathway [23]. Hence, telethonin protein changes cause a wide range of phenotype presentations from limb girdle muscle dystrophy $2 \mathrm{G}$ (LGMD2G), to severe distal weakness with proximal muscle involvement, congenital muscle dystrophy, proximal muscle weakness with involvement of facial muscle with tibial sparing [24], as well as proximal weakness [25].

TRIM-32 functions as a part-E ubiquitin ligase and is expressed mainly in proximal muscles, as well as in the gastrocnemius. It binds to the head and neck of myosin molecules and participates in ubiquitination of actin. Muscle stem cell differentiation during muscle regeneration is influenced by TRIM-32. This dual mode of action may explain the clinical presentation of both proximal (LGMD2H) [26], and distal weakness.

\section{Discussion and Conclusion}

The distribution of muscle involvement and weakness in primary muscle disease is an enigma. Since distal and proximal muscles have different functions and physiology, it is tempting to hypothesize that the function of the culprit gene product determines which set of muscles is involved. The present analysis attempts to shed some light on the mechanisms responsible for this disparity.

Our disease-by-disease examination of the metabolic/genetic abnormalities underlying chronic muscle disease, based on their cellular location and physiological function, provides convincing arguments to show that there are three venues responsible for the clinical phenotype.

1) Muscle diseases with proximal muscle dysfunction (proximal myopathies) are due to damaged associated muscle fiber membranes, or to muscle nuclear membranes with defective membrane repair mechanisms (Figure 2A). As proximal muscles are mainly responsible for eccentric contraction, defective proteins supporting this action that malfunction will present with proximal muscle wasting and weakness. Indeed, proteins causing proximal weakness are those supporting eccentric contraction that are membrane-bound, and thus are located on the outer cell membrane (sarcolemma) or inner membranes (SR and nuclear membranes). Therefore, mechanical injury due to 
Citation: Steiner I, Khlebtovsky A, Benninger F (2018) A Hypothesis for Mechanisms of Weakness Distribution in Muscular Dystrophies. J Neurol Disord 6: 389. doi:10.4172/2329-6895.1000389

\begin{tabular}{|c|c|c|c|c|}
\hline $\begin{array}{l}\text { The culprit } \\
\text { protein }\end{array}$ & Disease & Protein location & Protein function & Mechanism of myopathy \\
\hline Dystrophin & $\begin{array}{l}\text { Duchene, } \\
\text { Becker }\end{array}$ & Near muscle membrane & $\begin{array}{l}\text { Links actin filaments to the inside surface } \\
\text { of muscle fiber's plasma membrane } \\
\text { (sarcolemma). }\end{array}$ & $\begin{array}{l}\text { Instability of muscle membrane during } \\
\text { contraction, leads to muscle damage during } \\
\text { contraction. }\end{array}$ \\
\hline Sarcoglycan & LGMD2C-2F & Muscle membrane & Part of dystrophin-sarcocglycan complex. & $\begin{array}{l}\text { Muscle membrane is over susceptible to } \\
\text { mechanical injury because of dysfunction of } \\
\text { dystrophin sarcoglycan complex. }\end{array}$ \\
\hline Caveolin-3 & LGMD1C & Muscle membrane & $\begin{array}{l}\text { Interacts with dystrophin and dysferlin, } \\
\text { participates in preservation of stability of } \\
\text { muscle membrane. }\end{array}$ & $\begin{array}{l}\text { Abnormal interaction with dystrophin; retention } \\
\text { of caveolin molecules in Golgi apparatus; } \\
\text { defective interaction with dysferlin; reduction of } \\
\text { mechanoprotection of muscle membrane. }\end{array}$ \\
\hline Collagen VI & Bethlem myopathy & $\begin{array}{l}\text { Outer surface of muscle } \\
\text { membrane }\end{array}$ & $\begin{array}{l}\text { Synthesized by fibroblasts, has regulatory } \\
\text { functions. }\end{array}$ & $\begin{array}{l}\text { Unknown. Possible mechanism: } \\
\text { 1) Loss of collagen VI causes excessive } \\
\text { muscle stiffness and abnormal muscle } \\
\text { regeneration via satellite cell dysfunction } \\
\text { 2) Defective autophagy }\end{array}$ \\
\hline Lamin A/C & LGMD1B & $\begin{array}{l}\text { Inner part of nuclear } \\
\text { membrane, part of nuclear } \\
\text { envelope }\end{array}$ & $\begin{array}{l}\text { Might be involved in determination of } \\
\text { nuclear shape and size, organization of } \\
\text { nuclear pores and chromatin structure } \\
\text { and gene expression. Mutation in lamins } \\
\text { may change desmin localization and } \\
\text { mechanotransduction. }\end{array}$ & $\begin{array}{l}\text { Unknown. Possible mechanism: } \\
\text { 1.Loss of stability of nuclear envelope and } \\
\text { changes in mechanotranduction. } \\
\text { 2.Changes in gene transcription }\end{array}$ \\
\hline Emerin & Emery Dreifuss & Nuclear envelope & $\begin{array}{l}\text { 1) Mediates nuclear membrane anchorage } \\
\text { to the cytoskeleton. } \\
\text { 2) Connected to lamin, BAF and Btf (death } \\
\text { promoting transcriptor receptor). } \\
\text { 3) May influence actin dynamics. } \\
\text { 4) Interacts with gene proteins. }\end{array}$ & $\begin{array}{l}\text { Unknown. Possible mechanism: } \\
\text { 1) Changes in connection between lamin } \\
\text { and cytoskeleton cause changes in nuclear } \\
\text { membrane stability. } \\
\text { 2) Changes signaling and in genetic content } \\
\text { with destruction of DNA and satellite cell } \\
\text { dysfunction. }\end{array}$ \\
\hline
\end{tabular}

Table 1: Proteins causing proximal muscle dystrophy are briefly reviewed according to protein location, function, possible mechanism of myopathy and level of proof for the pathophysiological mechanism/s. A high level of proof exists for dystrophin, sarcoglicans, caveolin-3, emerin and LaminA/C proteins.

\begin{tabular}{|c|c|c|c|c|}
\hline The culprit protein & Disease & Protein location & Protein function & Mechanism of myopathy \\
\hline ZASP & Markesbury- Griggs & Z-disk & $\begin{array}{l}\text { Binds to a-actinin that crosslinks thin } \\
\text { filaments of sarcomeres, protecting } \\
\text { the integrity of sarcomeres, and also } \\
\text { interacts with actin. }\end{array}$ & $\begin{array}{l}\text { Unknown. Possible disruption of sarcomere } \\
\text { integrity. }\end{array}$ \\
\hline Myosin heavy chain -7 & Gower-Laing & $\begin{array}{c}\text { Main myosin isoform in type } \\
\text { I slow fibers }\end{array}$ & Muscle contraction. & $\begin{array}{c}\text { Unknown. Possible abnormal myosin assembly } \\
\text { and creation of myosin aggregates. }\end{array}$ \\
\hline CRYAB & $\begin{array}{l}\text { aB-crystalline mutated } \\
\text { distal myopathy }\end{array}$ & Near sarcomere & $\begin{array}{l}\text { Chaperon activity, heat shock protein, } \\
\text { protection from oxidative stress }\end{array}$ & $\begin{array}{l}\text { Unknown. Possibly impairs heat shock protein } \\
\text { activity, defective protection from oxidative } \\
\text { stress and cytotoxic injury, interaction with actin. }\end{array}$ \\
\hline GNE epimerase & $\begin{array}{l}\text { Distal myopathy with } \\
\text { rimmed vacuoles } \\
\text { ("Nonaka") }\end{array}$ & $\begin{array}{l}\text { Cytoplasm near Golgi } \\
\text { apparatus and nucleus }\end{array}$ & $\begin{array}{c}\text { Rate limiting enzyme in the sialic acid } \\
\text { biosynthesis pathway that is essential } \\
\text { in protein glycosylation, cell adhesion } \\
\text { and signal transduction. }\end{array}$ & $\begin{array}{l}\text { Unknown, possibly causes hypoglycosylation, } \\
\text { mitochondrial, sarcomere organization and } \\
\text { ubiquitination pathway problems. }\end{array}$ \\
\hline VCP & $\begin{array}{l}\text { VCP mutated distal } \\
\text { myopathy }\end{array}$ & $\begin{array}{l}\text { Expressed in different parts } \\
\text { of the cell }\end{array}$ & $\begin{array}{l}\text { VCP is involved in regulation of } \\
\text { cell cycle, apoptosis and protein } \\
\text { ubiquitination, and mitochondrial } \\
\text { function. }\end{array}$ & $\begin{array}{l}\text { Interferes in one or more processes carried by } \\
\text { VCP. }\end{array}$ \\
\hline KLHL9 & $\begin{array}{l}\text { KLHL9 mutated distal } \\
\text { myopathy }\end{array}$ & Cytoplasm & $\begin{array}{l}\text { KLHL9 binds to Cul3 and forms an } \\
\text { E3 ubiquitin ligase complex. }\end{array}$ & Disrupts KLHL9 -Cul3 complex. \\
\hline Matrin-3 & VCPDM & Nucleus & DNA repair and mRNA stabilization & $\begin{array}{c}\text { Unknown. Possibly impairs DNA repair and } \\
\text { RNA stabilization. }\end{array}$ \\
\hline
\end{tabular}

ZASP- Z: Band Alternatively Spliced PDZ Motif-Containing Protein; CRYAB: Ab-Crystallin; GNE Epimerase: Glucosamine (UDP-N-Acetyl)-2-Epimerase/NAcetylmannosamine Kinase; VCP: Vasoline Containing Protein; KLHL9: Kelch-Like Homologue 9; VCPDM: Vocal Cord Pharyngeal Distal Myopathy and LGMD: Limb Girdle Muscular Dystrophy.

Table 2: Proteins causing distal muscle dystrophy are briefly reviewed according to protein location, function, possible mechanism of myopathy and levels of proof of the pathophysiological mechanism/s. Exact pathological processes are obscure in most myopathies of this type.

eccentric contractions damages the membrane structures in the proximal muscles.

2) In muscle disorders that have a predominantly distal distribution, the responsible abnormality lies in a defective protein associated with sarcomere function, namely concentric contraction that causes muscle shortening. This action is mainly confined to distal muscles (Figure 2B).

3) Most intriguing are those MDs that involve both proximal and distal muscles. In our hypothesis this group was the "internal control". If indeed phenotype is the outcome of both function 
Citation: Steiner I, Khlebtovsky A, Benninger F (2018) A Hypothesis for Mechanisms of Weakness Distribution in Muscular Dystrophies. J Neurol Disord 6: 389. doi:10.4172/2329-6895.1000389

Table 3: Mutations in these proteins cause different phenomenological presentation, some cause proximal and some distal weakness. Both types are briefly reviewed according to protein location, function, possible mechanism of myopathy and levels of proof for the pathophysiological mechanism/s. Best levels of proof exists for titin, dysferlin and nebulin caused myopathies. The cause of myotilin caused myopathy is unknown.

\begin{tabular}{|c|c|c|c|c|c|c|c|c|}
\hline The culprit protein & \multicolumn{2}{|c|}{ Disease } & \multicolumn{2}{|c|}{ Protein location } & \multicolumn{2}{|c|}{ Protein function } & \multicolumn{2}{|c|}{ Mechanism of myopathy } \\
\hline Titin & \multicolumn{2}{|c|}{$\begin{array}{l}\text { Tibial muscular dystrophy } \\
\text { (distal) } \\
\text { LGMG 2J (proximal) }\end{array}$} & \multicolumn{2}{|c|}{$\begin{array}{l}\text { Protrudes between two } \\
\text { sarcomeres, connected to } \\
\text { Z-line proteins and M-line } \\
\text { proteins }\end{array}$} & \multicolumn{2}{|c|}{$\begin{array}{l}\text { Giant protein that connects to actin filaments } \\
\text { and myosin and is responsible for muscle } \\
\text { elasticity. Plays role in muscle contraction } \\
\text { and probably in signaling. }\end{array}$} & \multicolumn{2}{|c|}{$\begin{array}{l}\text { Dysfunction of titin kinase. Explanations } \\
\text { for dual phenotype includes: secondary } \\
\text { calpain- } 3 \text { deficiency and different titin } \\
\text { isoform expression in different type of } \\
\text { muscles. }\end{array}$} \\
\hline Nebulin & \multicolumn{2}{|c|}{$\begin{array}{l}\text { Distal nebulin myopathy } \\
\text { (distal) } \\
\text { Nemaline rod myopathy } \\
\quad \text { (proximal > distal) }\end{array}$} & \multicolumn{2}{|c|}{ Sarcomere } & \multicolumn{2}{|c|}{$\begin{array}{l}\text { Giant protein that connects to actin and } \\
\text { Z-disk, stabilizes thin filaments, is responsible } \\
\text { for muscle elasticity, and influences muscle } \\
\text { contraction by interacting with actin and } \\
\text { tropomyosin. }\end{array}$} & \multicolumn{2}{|c|}{$\begin{array}{l}\text { Unknown, possibly causes changes } \\
\text { in length of thin filaments and forces } \\
\text { reduction and abnormal involvement in } \\
\text { muscle contraction. }\end{array}$} \\
\hline Dysferlin & \multicolumn{2}{|c|}{$\begin{array}{l}\text { Miyoshi myopathy (distal) } \\
\text { LGMD2B (proximal) }\end{array}$} & \multicolumn{2}{|c|}{ Muscle membrane } & \multicolumn{2}{|c|}{$\begin{array}{l}\text { Membrane repair. Interacts with caveolin- } 3 \\
\text { and modulated by calpain- } 3 \text {. }\end{array}$} & \multicolumn{2}{|c|}{$\begin{array}{c}\text { Muscle susceptibility to injury and } \\
\text { delayed muscle repair after injury, and } \\
\text { probably causes mitochondrial } \\
\text { dysfunction. }\end{array}$} \\
\hline Desmin & \multicolumn{2}{|c|}{$\begin{array}{l}\text { Desmin myopathy (distal) } \\
\text { LGMD1E (proximal) }\end{array}$} & \multicolumn{2}{|c|}{$\begin{array}{l}\text { Intermediate filament. } \\
\text { Located near Z-disk and } \\
\text { sarcolemma }\end{array}$} & \multicolumn{2}{|c|}{$\begin{array}{l}\text { Connects sarcomeres to the nuclei, } \\
\text { extracellular matrix and sarcolemma; and } \\
\text { acts in muscle contraction. }\end{array}$} & \multicolumn{2}{|c|}{$\begin{array}{l}\text { Unknown. Possible destruction of } \\
\text { mesh of intermediate filaments and } \\
\text { toxic desmin aggregpation; changes in } \\
\text { transduction and muscle strength and } \\
\text { mitochondrial dysfunction }\end{array}$} \\
\hline Myotilin & \multicolumn{2}{|c|}{$\begin{array}{l}\text { Myotillin distal muscular } \\
\text { dystrophy (distal) } \\
\text { LGMD1A (proximal) }\end{array}$} & \multicolumn{2}{|l|}{ Z-disk } & \multicolumn{2}{|c|}{$\begin{array}{l}\text { Binding of } \alpha \text {-actinin protein, crosslinks } \\
\text { actin filaments of sarcomere and controls } \\
\text { sarcomere assembly; also connected to } \\
\text { sarcolemma via muscle specific filaments. }\end{array}$} & \multicolumn{2}{|c|}{$\begin{array}{l}\text { Unknown. Possible defective myofibril } \\
\text { reorganization after exercise }\end{array}$} \\
\hline Filamin-C & \multicolumn{2}{|c|}{$\begin{array}{l}\text { Distal ABD filaminopathy } \\
\text { (distal)Proximal weakness } \\
\text { in several German families } \\
\text { (proximal) }\end{array}$} & \multicolumn{2}{|c|}{$\begin{array}{l}\text { Z-disk and near muscle } \\
\text { membrane }\end{array}$} & Crosslinks & s actin filaments. & \multicolumn{2}{|c|}{$\begin{array}{l}\text { Unknown, possibly causes structural } \\
\text { changes in filamin leading to changes in } \\
\text { interaction with actin and aggregation of } \\
\text { filamin and its associated proteins. }\end{array}$} \\
\hline \multicolumn{9}{|c|}{ LGMD: Limb Girdle Muscular Dystrophy; ABD: Actin Binding Domain. } \\
\hline \multicolumn{9}{|c|}{$\begin{array}{l}\text { Table 4: Abnormal proteins that present with more or less simultaneous involvement of proximal and distal muscles are briefly reviewed according to: protein location and } \\
\text { unction, name of disease caused with possible mechanisms of myopathy, and levels of proof for the pathophysiological mechanism/s. Proteins in this group have a wide } \\
\text { ange of functions, including: cell signalling, muscle differentiation and apoptosis. However, the pathophysiology causing myopathy is unknown. }\end{array}$} \\
\hline Protein & Disease & \multicolumn{2}{|c|}{ Type of myopathy } & \multicolumn{2}{|c|}{ Protein location } & \multicolumn{2}{|l|}{ Protein function } & Mechanism of myopathy \\
\hline Calpain-3 & LGMD2A & Pro & ximal and distal & $\begin{array}{r}\text { Near ti } \\
\text { area, } \\
\text { mu }\end{array}$ & $\begin{array}{l}\text { in at the sarcomere } \\
\text { nucleus and near } \\
\text { scle membrane }\end{array}$ & $\begin{array}{r}\text { Participates in sarcome } \\
\text { membrane remodelin } \\
\text { promotion of myofibrillar } \\
\text { turnover; interacts with dys } \\
\text { sarcoglycans via filam }\end{array}$ & $\begin{array}{l}\text { ere and } \\
\text { ig via } \\
\text { r protein } \\
\text { sferlin and } \\
\text { nin-C. }\end{array}$ & $\begin{array}{c}\text { Unknown. Possible } \\
\text { mechanisms include } \\
\text { interactions with dysferlin } \\
\text { and titin, muscle remodeling, } \\
\text { cytoskeleton regulation, } \\
\text { excessed apoptosis and loss } \\
\text { of proteolytic activity. }\end{array}$ \\
\hline Telethonin & LGMD2G & & oximal > distal & & Z-disk & $\begin{array}{l}\text { Is a substrate of titin kinas } \\
\text { to the titin at its C-part a } \\
\text { domains and may be cri } \\
\text { sarcomere assembly a } \\
\text { regulatory function }\end{array}$ & $\begin{array}{l}\text { se. Binds } \\
\text { at Z1-Z2 } \\
\text { ritical to } \\
\text { and cell } \\
\text { as. }\end{array}$ & $\begin{array}{l}\text { Unknown, possibly elevated } \\
\text { muscle stiffness and inhibition } \\
\text { of muscle cell differentiation. }\end{array}$ \\
\hline TRIM 32 & LGMD2H & & oximal > distal & $\begin{array}{l}\text { Nucle } \\
\text { bodies } \\
\text { in he } \\
\text { and di } \\
\text { expres }\end{array}$ & $\begin{array}{l}\text { Is and cytoplasmic } \\
\text { expressed mostly } \\
\text { amstrings, soleus } \\
\text { aphragm. Very low } \\
\text { sion at quadriceps } \\
\text { and triceps }\end{array}$ & $\begin{array}{l}\text { 1) Ubiquitin ligase, that in } \\
\text { with myosin head and ubi } \\
\text { actin, and is involved in } \\
\text { degradation and constructi } \\
\text { remodelling. } \\
\text { 2) Regulates muscle st } \\
\text { differentiation essential fo } \\
\text { regeneration. }\end{array}$ & $\begin{array}{l}\text { interacts } \\
\text { iquitinates } \\
\text { muscle } \\
\text { tion during } \\
\text { tem cell } \\
\text { or muscle }\end{array}$ & $\begin{array}{l}\text { Unknown, possibly involved in } \\
\text { abnormal protein ubuititation, } \\
\text { stem cell dysfunction and loss } \\
\text { of ability for self-activation. }\end{array}$ \\
\hline
\end{tabular}

and cellular location of culprit genes, proteins that are associated with proximal and distal wasting should have either dual location and/or double function. This was the case in most but not all instances (Tables 3 and 4). To this group also belong patients with defects in proteins with a wide range of intracellular function, such as sarcomere and muscle membrane remodeling and repair and regulation of ionic channels' apoptosis (Figure 2C). Because of these important and diverse functions, mutations in these proteins may impair key mechanisms in muscle function, causing combined type of weakness.
Still, there are exceptions to this rule; the most important is dysferlin, a multifunctional protein located on the muscle cell membrane that causes proximal myopathy. As this protein is also associated with primary distal involvement in Miyoshi myopathy, one may postulate that this phenotype is mediated through the action of calpain-3, located near the sarcomere.

It should be emphasized that our hypothesis attempts to explain the distribution of muscle weakness only in degenerative muscle disorders. The distribution of weakness in other types of muscle diseases (inflammatory, endocrine, etc.) is probably more complex because 
Citation: Steiner I, Khlebtovsky A, Benninger F (2018) A Hypothesis for Mechanisms of Weakness Distribution in Muscular Dystrophies. J Neurol Disord 6: 389. doi:10.4172/2329-6895.1000389

additional factors are involved other than proper protein dysfunction and muscle cell signaling. Furthermore, the degenerative muscle diseases caused by more complicated mechanisms than isolated protein dysfunction, such as myotonic dystrophy and facioscapulohumeral muscular dystrophy, represent exceptions to our hypothesis.

\section{Implications of the Hypothesis}

This rule of distribution of weakness could be useful for deciphering the function of an abnormal muscle fiber protein associated with a clinical phenotype. When the condition is characterized by proximal muscle weakness and atrophy, it might be reasonable to speculate that its function and location is associated with membrane integrity. Likewise, abnormal proteins causing distal muscle disease should be suspected to contribute to sarcomere action. Thus, by identifying the distribution pattern of the muscle weakness in a patient, it may be possible to predict the intracellular location of the culprit protein.

\section{References}

1. Davies KE, Nowak KJ (2006) Molecular mechanisms of muscular dystrophies: Old and new players. Nat Rev Mol Cell Biol 7: 762-773.

2. Pasternak C, Wong S, Elson EL (1995) Mechanical function of dystrophin in muscle cells. J Cell Biol 128: 355-361.

3. Biggar WD (2006) Duchenne muscular dystrophy. Pediatr Rev 27: 83-88.

4. Parton RG, Simons K (2007) The multiple faces of caveolae. Nat Rev Mol Cell Biol 8: 185-194.

5. Baker NL, Mörgelin M, Pace RA, Peat RA, Adams NE, et al. (2007) Molecular consequences of dominant bethlem myopathy collagen $\mathrm{VI}$ mutations. Ann Neurol 62: 390-405.

6. Muchir A, Bonne G, Van der Kooi AJ, Van Meegen M, Baas F, et al. (2009) Identification of mutations in the gene encoding lamins $A / C$ in autosomal dominant limb girdle muscular dystrophy with atrioventricular conduction disturbances (LGMD1B). Hum Mol Genet 9: 1453-1459.

7. Manilal S, Nguyen TM, Sewry CA, Morris GE (1996) The Emery-Dreifuss muscular dystrophy protein, emerin, is a nuclear membrane protein. Hum Mol Genet 5: 801-808.

8. Udd B (2012) Distal myopathies - New genetic entities expand diagnostic challenge. Neuromuscul Disord 22: 5-12.

9. Laing NG, Laing BA, Meredith C, Wilton SD, Robbins P, et al. (1995) Autosomal dominant distal myopathy: linkage to chromosome 14. Am J Hum Genet 56: 422-427.

10. Huizing M, Krasnewich DM (2009) Hereditary Inclusion Body Myopathy: A decade of progress. Biochim Biophys Acta - Mol Basis Dis 1792: 881-887.
11. Palmio J, Sandell S, Suominen T, Penttila S, Raheem O, et al. (2011) Distinct distal myopathy phenotype caused by VCP gene mutation in a finnish family. Neuromuscul Disord 21: 551-555.

12. Dhanoa BS, Cogliati T, Satish AG, Bruford E , Friedman JS (2013) Update on the Kelch-like (KLHL) gene family. Hum Genomics 7: 13.

13. Salton M, Elkon R, Borodina T, Davydov A, Yaspo ML, et al. (2011) Matrin 3 binds and stabilizes mRNA. PLoS One 6: 1-7.

14. Nigro V, Aurino S, Piluso G (2011) Limb girdle muscular dystrophies: update on genetic diagnosis and therapeutic approaches. Curr Opin Neurol 24: 429-436.

15. Herzog W (2014) The role of titin in eccentric muscle contraction. J Exp Bio 217: $2825-2833$.

16. Aoki M, Liu J, Richard I, Bashir R, Britton S, et al. (2011) Genomic organization of the dysferlin gene and novel mutations in Miyoshi myopathy. Neurology 57: 271-278.

17. Dalakas MC, Park KY, Semino-Mora C, Lee HS, Sivakumar KGL (2000) Desmin myopathy, a skeletal myopathy with cardiomyopathy caused by mutations in the desmin gene. N Engl J Med 342: 770-780.

18. Greenberg SA, Salajegheh M, Judge DP, Feldman MW, Kuncl RW, et al. (2012) Etiology of limb girdle muscular dystrophy $1 \mathrm{D} / 1 \mathrm{E}$ determined by laser capture microdissection proteomics. Ann Neurol 71: 141-145.

19. Hauser MA, Horrigan SK, Salmikangas P, Torian UM, Viles KD, et al. (2000) Myotilin is mutated in limb girdle muscular dystrophy $1 \mathrm{~A}$. Hum Mol Genet 9 : 2141-2147.

20. Pénisson-Besnier I, Talvinen K, Dumez C, Vihola A, Dubas F, et al. (2006) Myotilinopathy in a family with late onset myopathy. Neuromuscul Disord 16 427-431.

21. Gontier Y, Taivainen A, Fontao L, Sonnenberg A, Van der Flier A, et al. (2005) The Z-disc proteins myotilin and FATZ-1 interact with each other and are connected to the sarcolemma via muscle-specific filamins. J Cell Sci 118: 3739-3749.

22. Kramerova I, Beckmann JS, Spencer MJ (2007) Molecular and cellular basis of calpainopathy (limb girdle muscular dystrophy type 2A). Biochim Biophys Acta 1772: $128-144$.

23. Markert CD, Meaney MP, Voelker KA, Grange RW, Dalley HW, et al. (2010) Functional muscle analysis of the Tcap knockout mouse. Hum Mol Genet 19: 2268-2283.

24. Cotta A, Paim JF, da-Cunha-Junior AL, Neto RX, et al. (2014) Limb girdle muscular dystrophy type $2 \mathrm{G}$ with myopathic-neurogenic motor unit potentials and a novel muscle image pattern. BMC Clin Patho 14: 41.

25. Olivé M, Shatunov A, Gonzalez L, Carmona O, Moreno D, et al. (2008) Transcription-terminating mutation in telethonin causing autosomal recessive muscular dystrophy type $2 \mathrm{G}$ in a European patient. Neuromuscul Disord 18: 929-933.

26. Cohn RD, Campbell KP (2000) Molecular basis of muscular dystrophies Muscle Nerve 23: 1456-1471. 